KAIROS ELT JOURNAL, Vol. 2, No. 1, April 2018

Copyright@2018, ISSN: 2580-4278

\title{
IMPROVING STUDENTS' READING ACHIEVEMENT IN COMPREHENDING NARRATIVE TEXT BY APPLYING THINK PAIR SHARE TECHNIQUE AT SMP SANTO PETRUS MEDAN
}

\author{
Peber Wanta br Tarigan, Linus Rumapea, Novalina Sembiring \\ Catholic University of Saint Thomas
}

\begin{abstract}
This research is about improving students' reading achievement in comprehending narrative texts by apply Think Pair Share technique at SMP Santo Petrus Medan class VIII-4 in academic year 2016/2017. The aim of this research is to improve students' reading comprehension through Think Pair Share technique. This technique applies by theory Cooper. The objectives of this research are to find out how could Think Pair Share technique improve students' reading comprehension and how good are the second grade students of SMP Santo Petrus Medan in reading comprehension after having been taught through the Think Pair Share technique. The research was a Classroom Action Research (CAR) which was conducted by applying Think Pair Share technique in teaching reading to the eighth grade students of class VIII-4. It could be seen that there is a significant improvement of students' reading comprehension. In this research, the data are distinguished into qualitative and quantitative data. The quantitative data are pretest and posttest. The qualitative data consists of field notes, observation and interview. The result of this research shows that the students' mean score in pretest is 61,20 with $27,28 \%$ of the students get score $\geq 70$ and in the posttest mean score is 75,51 with $82,75 \%$ of the students get score $\leq 70$. It shows that there is a significant mean score improvement between pretest and posttest about 55,17\%. It is suggested that the teachers use the Think Pair Share technique as alternative technique in teaching reading to the students in Junior High School in order to improve students' reading comprehension.
\end{abstract}

Keywords: reading comprehension, think pair share technique

\section{INTRODUCTION}

Reading is an important skill to get information and knowledge from the text that should be mastered by junior high school students. Through reading, students can obtain many inspirations so that they will be more creative. Reading is a good way to find out about new ideas, facts, and experiences. Grabe and Stoller (2002:4) state that reading can be thought of as a way to draw information from a text and to form an interpretation of that information. It means comprehending and mastering are the key to understand of the content in a text. It implies that students need to learn a considerable amount of information from a text.

Reading comprehension is the activity where the students actually understand what they read about. Snow (2002:11) states that reading comprehension as the process of simultaneously extracting and constructing meaning through interaction and involvement with written language. A successful comprehension occurs if it involves the reader to discover the meaning needed to achieve the particular purposes in a text. It relates to understanding and thinking process to get the message from the reading materials. In junior high school, the students are expected to comprehend reading text. In reading skill, the students are expected to comprehend the content of the text and textual meaning by using narrative text to identify main idea and the meaning of the words. The students are expected to understand what passage is about that is given by the teacher.

My observation toward the eighth grade students of SMP Santo Petrus Medan Class VIII-4 in the Academic Year of 2016/ 2017 during English class showed that some of students 
have mistakes in interpreting the main idea in each paragraph and in the entire texts. Most of the students could not answer the questions about the text correctly. I also interviewed three students out of thirty students. They are AT, PS, and PA. When I asked them about their reading ability, they said that comprehending a text is difficult because they find a lot of unfamiliar words in a text and the students did not pay attention to the lesson and it made them could not understand the lesson taught by the teacher since they were busy talking each other (Limbong et al., 2016).

I made an interview to the English teacher. From the result of the interview, it showed that the eighth grade of junior high school students had a problem in reading. When I asked about the students' reading ability, the teacher said that the students weak in reading comprehension. From the pre-observation and interview done in pre-research, I found that there were some difficulties faced by the students in reading comprehension: First, they had difficulties to understand the context and get the information of the story so the students failed to understand longer reading materials such as stories. Second, most students had an ability to translate the individual words without conveying the message what the author extends. Third, the students were lack of motivation in reading English text. Finally, spent much time to answer the comprehension questions related to the text and copy their friends' work. Those all made their achievement low and caused failure in teaching and learning process. So, they had problem in comprehending the English reading text.

When I gave exercise, some of students could not understand the text. The results of their exercise were also low scores and only some of students got score $\geq 70$. It could be seen from the result of pretest which showed that there were 8 students from 29 students got score $\geq 70$ and fulfilled the KKM (Kriteria Ketuntasan Minimum) while most of the students got score $<70$. So, I found that the students had different reading comprehension. Some of them were good readers but others had reading problems.

Based on the condition, it could be concluded that it needs a technique in teaching reading. In order to make the students feel more motivated to study reading. So I used Think Pair Share technique to improve their motivation in studying reading. I will apply this method at SMP Santo Petrus Medan class VIII-4 in academic year 2016/2017. This research was hoped can improve the students' motivation in studying reading comprehension.

Think Pair Share technique is a cooperative learning model that allow the students to work together to complete the assignment in the class. Therefore, each member of a team was responsible not only for learning what was taught but also for helping teammates learn. Jolliffe (2007:13) states that cooperative learning has potential as a powerful teaching strategy in inclusive classrooms impacting both academic and social skills'. In cooperative learning, students work in groups to teach themselves the content being covered.

I assume that all activities of teaching reading comprehension skill using Think Pair Share technique could improve their activity and their reading comprehension. On Think Pair Share technique, students trained how to express their opinion and also students be given an opportunity to participate in the class. Through this technique, students can improve the system of cooperation in team so that the students prosecuted for empathy, and can learn to receive the opinions of friends in the team.

Based on the background, I will conduct a research entitled "Improving Students' Reading Achievement in Comprehending Narrative Text by Applying Think Pair Share Technique at SMP Santo Petrus Medan Class VIII-4 in the Academic Year 2016/2017”.

\section{REVIEW OF LITERATURE Reading}

Reading is able to read the words. It means reading is a mental activity which readers do to find out information and knowledge. Aderson in Nunan (2003:68) states that reading is a

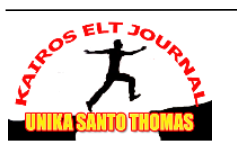


fluent process of readers combining information from a text and their own background knowledge to build meaning. It means that students able to comprehend and to find the main idea in the content of text.

Meanwhile, Brown (2001:189) states that reading is a process of a negotiation of meaning. It means that students combine information from text and their background knowledge to build meaning. They have to employ all knowledge in their brain to make sense of text and they pay attention to the text itself for the words, phrases, clauses, sentences, and the connection between sentences to comprehend the text.

Based on the explanations, reading is one of important skill that students must comprehend because by reading students can improve their knowledge, information, news, attitudes and they can enrich their vocabulary.

\section{Reading Comprehension}

Reading is a way in which something is interpreted or understood. It does not mean that reading only understands the words or the grammar but reading is the comprehending the content of text. Reading comprehension is the ability to read the text and understand its meaning. Kingner, Vaughn and Boardman (2007:8) state that:

Reading comprehension is multi component, highly complex process that involves many interactions between readers and what they bring to the text (previous knowledge, strategy use) as well as variables related to the text itself (interest in text, understanding of text types).

So, there is an interaction between the text and the reader that constitute actual reading. The goal is to gain an overall understanding of what is described in the text.

Reading comprehension is ability of students to comprehend and to get information or message on the text. Heilman, et.al (1981:242) states that reading comprehension is a process of making sense of written ideas through meaningful interpretation and interactions with language. It means reading is the activity that students do to clarify the content of text through their simple words. Westwood (2007:31) states that reading comprehension can be defined as an active thinking process through which a reader intentionally constructs meaning to form a deeper understanding of concepts and information presented in a text. It means students must know the meaning of the word in the texts.

Based on the explanations, reading comprehension is defined as the ability of students in finding main idea or general information from the content of text that they read. It means, reading comprehension is the process to grasp meaning from the content of the text.

Students have goal in reading comprehension. The goal of reading is students able to interpret what they read. Grabe and Stoller (2002:13-15) state there are some purposes of reading:

1) Reading to search for simple information and reading to skim.

Reading to search for simple information is common reading ability, though some researchers are see it as a relatively independent cognitive process. In reading to search, we typically scan the text for a specific word. As an example, we usually search through a telephone directory to find key information, either an address or a phone number.

2) Reading to learn from text.

This purpose usually exists in academic and professional contexts. It happens when the reader needs to learn important information from a text. This purpose of reading needs the ability to memorize main ideas, recognize and build rhetorical frames in the texts and link the text to the reader's background knowledge. The reading rates when reading to learn is slower than general reading comprehension because it requires a deep comprehension of the text. Therefore, the reader sometimes should reread and reflect the text in order to remember information.

3) Reading to integrate information, to write, and to critique text.

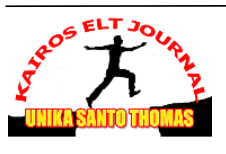


When the reader's purpose is to integrate information, to write, and to critique texts, the reader has to decide what information to integrate and how to integrate it for the reader's goal. Also, the reader requires the ability compose, to select, and critique information from a text.

4) Reading for general comprehension.

Reading for general comprehension is the most basic purpose, underlying and supporting most other purposes of reading. This purpose is not easy as most people think about it.

Based on purposes of reading, it can be concluded that reading is the way to find messages or main idea from the text. In there the readers are able to understand the language use in text, understanding of language is the key to comprehend meaning of text. In the process of reading, the readers are influenced by their purpose for reading.

\section{Types of Reading}

Brown (2003:189) states that there are four types of reading performance are typically identified, and these will serve as organizers of various assessment tasks, there are:

1) Perceptive

Perceptive reading tasks involve attending to the components of larger stretches of discourse: letters, words, punctuation, and other graphitic symbols. In this case the learners are expected becoming literate in both of their native speaker or in language that they have learned. By doing this task they will get a lot benefits, one of it is they able to write and read.

2) Selective

This category is largely an artifact of assessment formats. In order to ascertain one's reading recognition of lexical, grammatical, or discourse features of language within a very short stretch of language, certain typical task are used: picture-cued tasks, matching, true/false, multiple-choice, etc. It means that the learners are expected to understand more detail about the language that they have learned.

3) Interactive

Included among interaction reading types are stretches of language of several paragraphs to one page or more in which the reader must, in a psycholinguistic sense, interact with the text. That is, reading is a process of negotiating meaning: the reader brings to the text a set of schemata for understanding it, and intake is the product of that interaction. So the reader or listener have to make the text into graph or schemata in order to make simple and more easier in understanding it without reading the whole text. Hence the reader can understand immediately by looking the schemata with a little note in the below of it.

4) Extensive

Extensive reading, applies to texts of more than a page, up to including professional articles, essays, technical reports, short stories, and books. The learners must understand the whole text that they have read and the last they can answer the question based on the text.

Based on those types of reading, I know that perceptive reading, selective reading, interactive reading and extensive reading have different meaning. I will choose selective reading in reading comprehension because I will be given the test is multiple choices form.

\section{The Levels of Reading Comprehension}

Reading comprehension is considered to occur at four levels of complexity. According to Burns, Roe and Ross (1984:177) state that levels of reading comprehension are literal level, inferential level, critical level and creative level. Consider the following brief passage:

1) Literal Comprehension

Literal comprehension involves acquiring information that is directly stated, the basic of literal comprehension is recognizing the stated main idea, detailed caused effect and

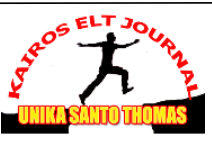


sequence. It is also prerequisite for higher-level understanding. The important in this level is understanding vocabulary, sentence meaning, and paragraph meaning.

2) Interpretative Comprehension

Interpretative comprehension involves reading between the lines or making inferences. It is the process of deriving ideas that are implied rather than directly stated. Skills for interpretative reading include: inferring main idea of passages in which the main idea are not directly stated, inferring cause-effect relationship when they are not directly stated, inferring referents of pronouns, inferring referent of adverbs, inferring omitted words, detecting mood, detecting the author's purpose in writing, drawing conclusion.

3) Critical Comprehension

Critical comprehension is evaluating written material comparing the ideas discovered in the material with known standards and drawing conclusion about their accuracy, appropriateness, and timeliness. The critical reader must be an active reader, questioning, searching for facts, and suspending judgment until he or she considered all of material. Critical reading depends upon literal comprehension, and grasping implied ideas is especially important.

4) Creative Comprehension

Creative comprehension involves going beyond the material presented by the author. It requires reader to think as they read, just as critical reading does and it also requires them to use imaginations. Through creative reading the reader creates something new idea, solution to a problem, a new way of looking at something from the ideas gleaned from the text.

Based on the levels of reading above, literal level, inferential level, critical level, and creative level are interconnected. It means, in reading comprehension students must be able master the first level until the fourth level. The levels of reading comprehension are the referral in reading that must students comprehend.

\section{Reading Strategies}

In reading comprehension, the readers have planning before they start reading the text. Zimmermann \& Hutchins in Moreillon (2007:11) state that seven reading comprehension strategies:

1) Activating or building background knowledge

This strategy can be taught by making text-to-self, text-to-text, and text-to-world connection before, during and after reading. Teacher-librarians and classroom teachers working in partnership can effectively model their thinking and demonstrate their individual prior knowledge, identify the need for additional background information, and share unique responses to texts. They can use questioning to provide students with windows into their own connections and help students understand how background knowledge is necessary information that makes texts more comprehensible.

2) Using sensory images

Using sensory images are part of the background knowledge that readers bring to text. Helping students utilize all their senses as they read texts supports their comprehension. Sensory images also have the potential to increase readers' enjoyment and memory of their literary experiences. Educators can add sensory input to literary engagements to dramatize the powerful influence of our senses on meaning making. Through modeling, educators share their unique sensory responses to the language and images presented in texts. Teacher-librarians and classroom teachers working in partnership can effectively model how to utilize one's own senses to comprehend text more fully and to gain increased pleasure from reading. Sensory images also help students store reading events in their memories. 
3) Questioning

Questioning is an essential component of reading comprehension, of conducting research, and of critical thinking. In short, questioning is a key to learning. Questioning may be more important than ever by providing readers with a path to follow. Instead of being overwhelmed by information, students can focus on asking and answering questions that are germane to their purposes. In the context of classroom-library collaboration, asking and answering questions while reading texts related to curriculum as well as texts of personal interest are essential to developing information literacy.

4) Making predictions and inferences

Predicting and inferring before, during, and after reading are comprehension strategies that can appeal to readers' sense of adventure and challenge. Some authors and illustrators have created texts that capitalize on these aspects of reading. Educators have a critical role in identifying exemplary texts that help students practice these strategies. When readers read on to test their hypotheses, their motivation, level of engagement, and enjoyment of texts can increase significantly. One important aspect of teaching prediction and inference is recognizing that whether readers' logical predictions or inferences match the authors' and illustrators' intentions is not as significant as the readers' active interaction with the text.

5) Determining main ideas

Determining the main idea may be one of the most valuable strategies a 21 st-century reader can develop. Sorting out what is important in the deluge of information is key to making sense and using information to generate knowledge. This is a complex process. Main ideas are always dependent on the purpose for reading and the judgment of the reader. Educators should give students the opportunity to engage with the same texts for different purposes.

6) Using fix-up options

Using the fix-up strategy is one the important tools students can develop to improve reading comprehension. Fix-up options are only as effective readers' ability to monitor their own understanding of texts. Educators and students can share the many ways they realize when they have lost track of the meaning of something they are reading. Think-aloud strategies are essential in helping readers understand the cognitive processes behind this strategy.

7) Synthesizing

Classroom-library collaboration to teach and to support students as they practice synthesizing information offers young people the opportunity to practice 21 st-century literacy skills. Although cannot predict what the world will be like when today's elementary students graduate from high school, they can feel certain that their daily lives will include accessing, evaluating, and using information. By guiding students through the information literacy process and requiring that their process include their own interpretations of the ideas and information they read and view, educators can help students develop the criticalthinking skills they will need to negotiate the challenges of the future

Based on the strategies, students should have strategies in reading comprehension. It aims to make students are easily to comprehend and to understand the content of text. 'So that, they are able to find out the main idea or opinion from what have been read and then they can share their opinion with their partner to discuss the content of texts.

\section{Think Pair Share Technique}

Think-Pair-Share technique allows students to learn from one another in learning process, to work together towards a common goal, and to practice tolerance. Tint $(2015: 2)$ states that the purposes of this technique are to process information, having a communication and develop thinking among students. This technique helps students become active participants in learning and can include writing as a way of organizing thoughts. It means in teaching 
learning process will be more fun and more active to tell their opinion with their partner. Furthermore, Moreillon (2007:158) states that:

Think Pair Share is the procedure, a question or problem is posed. Students think about a response or solution and turn to a partner to share their responses, and then the educators ask for volunteers to share with the larger group or whole class.

It means Think Pair Share technique is the cooperative learning that give solution for students to make the students understand about the lesson that teach by teacher in class.

Azlina (2010:23) states that Think-Pair-Share is a cooperative learning technique which is said as a multi-mode discussion cycle in which students listen to a question or presentation, have time to think individually, talk with each other in pairs, and finally share responses with the larger group. Think-Pair-Share technique also enhances the student's oral communication skills as they have an ample time to discuss their ideas with each other.

Based on definition, Think Pair Share technique is a cooperative learning that can help the students to solve their problems in reading narrative text. By using this technique, the teaching learning process will be more active and the students will develop their knowledge.

\section{The Steps of Think Pair Share Technique}

Think Pair Share technique consists of some steps. According to Cooper (1988:280) there are five steps of Think Pair Share technique:

1) Explain strategy to students

Before beginning the lesson, the teacher explains the Think Pair Share strategy: Students will have partners with whom they will exchange ideas during the lesson, whenever the teacher signals them to do.

2) Form Partnership

The teacher forms partnerships, using a simple pairing scheme, for example, having students count off in duplicate $-1,1 ; 2,2 ; 3,3 ; 4,4$; and so on. If necessary, the last group may be a three or the teacher may take partner.

3) Pose question; direct to "think"

At appropriate points during the lesson, the teacher poses a question and calls for a short "think-time," perhaps ten seconds or more, depending on the nature of the question. During this think time, students must remain silent, forming their own answers.

4) Signal "Share".

At a signal, usually just a word "share" or the sounding of a timer's bell, students turn to their partners and exchange answers, spending a minute to explain their thinking a resolve differences, if there are any.

5) Pairs report

At the end of share-time, the teacher asks a pair to report. The final step of Think Pair Share has several benefits to all students. They see the same concept expressed in several different ways as different individuals finds unique expression for an answer to the question. Moreover, the concepts embedded in the answer are in the language of the textbook or teacher.

Based on the steps, I will apply the steps. The purpose is guidance to me in dividing groups and through the steps, it is easy for me to apply the technique of Think Pair Share in classroom.

\section{RESEARCH METHOD}

Based on the problem, I conducted classroom action research design. Latief (2012:144) states that Classroom Action Research (CAR) is the media to increase the English teachers' quality in terms of performances of instruction as well as the students' achievement in learning 
English in a classroom effectively. It means Classroom Action Research is the action of teacher in giving solution to improve students' achievement students in learning.

Classroom action research is a simple research to solve the problem usually done by a teacher. Winter and Giddings (2001:8) state that action research is the study of a social situation carried out by those involved in that situation in order to improve both their practice and the quality of their understanding. It means in teaching learning, they need socialization each other to develop their knowledge through practice.

In the classroom action research teacher apply a method or technique in teaching and learning process to improve students' achievement. Mettetal (2001:8) states that classroom action research is a method of finding out what works best in teacher own classroom so that she or he can improve student learning. It means classroom action research is the method or way of teacher to solve the problem of students when they follow teaching learning.

\section{DATA ANALYSIS}

The data of this research was collected from the eighth grade students of SMP Santo Petrus Medan in academic year 2016/2017. In order to obtain reliable data for this research, as stated in Chapter III there were some research instruments administered to the subject under the study. Consequently, there were two raw data gathered for the present study which consisted of pre-test, post-test.

In this study, the data collected could be distinguished into quantitative and qualitative data. The quantitative data were shown by the students' scores which were collected by the administration of pre-test and post-tests. The pre-test was administered to measure the problems that the students faced in reading comprehension skill. Furthermore, the post-test was administered at the end of each session. The qualitative findings were obtained from interview carried out after cycle II was completed. It showed the response of the subjects under study towards the implementation of Think Pair Share technique in improving students' reading comprehension.

\section{The Qualitative Data}

The qualitative data consisted of the field notes, observation and interview. They were described as follows:

\section{Observation}

Observation was held on Thursday, 28 September 2016 at 07.30-08.10. The writer observed as follows:

- Before start lesson, the students and teacher prayed together and they listen to reflection morning that brought by one of the teachers at the school.

- Teacher greeted the students and asked the students to attention cleaning classroom.

- Teacher asked students that whether any homework.

- Teacher repeated the previous lesson in the class.

- The teacher asked the students read the text together.

\section{Interview}

Interview was held on Wednesday, 29 September 2016 at 10.20-10.35. I asked the teacher some questions about students' difficulties in reading, condition of the classroom, students' activity in classroom, students' achievement.

\section{Field Notes}

The field notes of each meeting are described as follows:

\section{a. Meeting 1: Pretest}

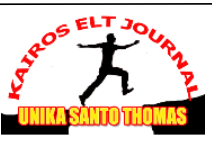


Meeting 1 was held on Thursday, 06 October 2016 at 07.15-08.10 hours in class VIII4. I entered the classroom together with mom P. Tarigan, the English teacher of students who also acted as my collaborator. Before the lesson was started, the students and teacher prayed together and they listened to reflection morning that was brought by one of the teachers at the school. Then, students gave greetings to the teacher. After that, mom Tarigan ordered me to introduced myself to the students and greeted the students by saying "Good morning students, nice to meet you" and they answered "Good morning Miss, nice to meet you too". The students were friendly to me.

Then, I told to students about my reason that I came to the school and distributed the pretest to the students and explained what the students would do in the pretest. I provided 40 minutes to do the multiple choices test which consisted of 20 items. I distributed 29 sheets and in the first meeting students of class VIII-4 were present. When students carried out the test, there were some students who asked about the test. They faced the difficulty in reading and comprehending the text, but I could not help them because of it was pretest so they should do it by themselves. When time was over, I collected the students' work. Then, I ended the class, greeted students and left the class.

\section{b. Meeting 2: Cycle 1}

Meeting 2 was held on Wednesday, 12 October 2016 at 08.50-10.10 hours in class VIII4. I came in to the class and greeted the students by saying "Good morning students, how are today?" and they answered "Good morning Miss, I am fine, and you?". Then I replied "I am fine, thank you". After greeting, I checked the attendance list. In class VIII-4 consisted of 29 students, 12 males and 17 females. At the time, students class VIII-4 was present.

I taught the students about the narrative text. In this meeting I explained the meaning of narrative text, the generic structure of narrative text, language feature narrative text, kinds of narrative texts and I gave some example the kinds of narrative texts. When I explained about narrative texts, I ordered the students keep their mouth. After I finished explain the lesson, I gave time to students to ask about the lesson that I taught for them. After the time was over, I gave the task to the students and suggested them to learn at home. Then, ended the class and asked one of the students to lead the prayer. After the prayer, I greeted the students and left the class.

\section{c. Meeting 3: Cycle 1}

Meeting 3 was held on Thursday, 13 October 2016 at 07.30-08.50 hours in class VIII4. I entered the classroom. Before starting the lesson, the students and teacher prayed together and they listened to reflection morning that was brought by one of the teachers at the school. Then, greeted the students by saying "Good morning students, how are today?" and they answered "Good morning Miss, I am fine, and you?". Then I replied "I am fine, thank you". After greeting, I checked their attendance list. In class VIII-4 consisted of 29 students, 12 males and 17 females. At the time, one of students was absent.

I started the teaching learning process by reviewing and recalled the lesson last meeting. For example, I asked about the meaning, the kinds, the generic structure and the example of narrative texts and I ordered the students to collect their homework. After I reviewed lesson last meeting and collect their homework, I divided them to be group (pair). Before that, I introduced my technique that I would apply in class. It was about Think Pair Share technique. And then, I divided them to be pair and I gave the title of narrative text to students about Lake Toba to discuss with their pair or peer.

Then I gave to them the general question to think individually that what they known about Lake Toba for 5 minutes. After that I asked them to share and to make report from what 
they thinking about the legend of Lake Toba with their partner or peer. When time was over, I collected the students' work

Before closing the lesson, I asked about students' difficulties in this meeting. Then, I gave the explanation and supported them to learn more. Then I said "Enough for today, and see you next time" and they answered "see you Miss". Then, I left the class.

\section{d. Meeting 4: Cycle 1}

Meeting 3 was held on Wednesday, October 192016 at 08.50-10.10 hours in class VIII4. I came in to the class and greeted the students by saying "Good morning students, how are today?" and they answered "Good morning Miss, I am fine, and you?". Then I replied "I am fine, thank you". After greeting, I checked their attendance list. In class VIII-4 consisted of 29 students, 12 males and 17 females. At the time, students class VIII-4 was present.

I started the teaching learning process by reviewing and recalled the lesson last meeting. For example, I asked about the narrative text entitled Lake Toba. For this meeting, I gave the test to evaluate their reading comprehension. The test formed multiple choices and the text in the test about Lake Toba. It was as formative test in Cycle 1. They did the test individually for 15 minutes. After they had finished do the test, I divided them to be pair and I gave the title of narrative text to students about Malin Kundang to discuss with their pair or peer.

Then I gave to them the general question to think individually that what they known about Malin Kundang for 5 minutes. After that I asked them to share and to make report from what they thinking about the legend of Lake Toba in their partner or peer. When the time was over, I asked the students what difficulties they had to make report about of legend Malin Kundang with their partner and suggested them to learn at home. Then, ended the class and asked one of the students to lead the prayer. After the prayer, I greeted the students and left the class.

\section{e. Meeting 5: Cycle 2}

Meeting 3 was held on Thursday, 20 October 2016 at $07.30-08.50$ hours in class VIII4. Before the lesson was started, the students and teacher prayed together and they listened to reflection morning that brought by one of the teachers at the school. Then, greeted the students by saying "Good morning students, how are today?" and they answered "Good morning Miss, I am fine, and you?". Then I replied " I am fine, thank you". After greeted the students, I checked their attendance list. In class VIII-4 consisted of 29 students, 12 males and 17 females. At the time, students class VIII-4 was present.

I started the teaching learning process by reviewing and recalled the lesson last meeting. For example, I asked about the narrative text entitled Malin Kundang and then I divided them to be pair and I gave the title of narrative text to students about The Lion and The Mouse to discuss with their pair or peer.

Then I gave to them the general question to think individually that what they known about The Lion and The Mouse for 5 minutes. After that, I asked them to share and to make report from what they thinking about fable of The Lion and The Mouse in their partner or peer. After they collected their report, I gave the test to evaluate their reading comprehension and they did the test individually. When time was over, I collected students' work.

Before closing the lesson, I asked about students' difficulties in this meeting. Then, I gave the explanation and supported them to learn more. Then I said "This the end our meeting for today and see you next time" and they answered "see you Miss". Then, I left the class.

\section{f. Meeting 6: Cycle 2}

Meeting 3 was held Wednesday, October 262016 at 08.50-10.10 hours in class VIII-4. I came in to the class and greeted the students by saying "Good morning students, how are

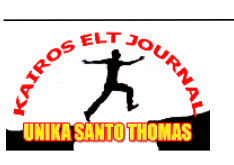


today?" and they answered "Good morning Miss, I am fine, and you?". Then I replied "I am fine, thank you". After greeting, I checked their attendance list. In class VIII-4 consisted of 29 students, 12 males and 17 females. At the time, students class VIII-4 was present.

I started the teaching learning process by reviewing and recalled the lesson last meeting. For example, I asked about the narrative text entitled The Lion and The Mouse and then I divided them to be pair and I gave the title of narrative text to students about Bawang Merah and Bawang Putih to discuss with their pair or peer.

Then I gave to them the general question to think individually that what they known about Bawang Merah and Bawang Putih for 5 minutes. After that, I asked them to share and to make report from what they thinking about folk tale of Bawang Merah and Bawang Putih in their partner or peer. After they finished they did their report, I asked them what difficulties they had to make report about folk tale of Bawang Merah and Bwang Putih with their partner. When the time was over, I gave the task to the students and suggested them to learn at home. Then, ended the class and asked one of the students to lead the prayer. After the prayer, I greeted the students and left the class.

\section{g. Meeting 7: Cycle 2}

Meeting 3 was held on Thursday, 27 October 2016 at 07.30-08.50 hours in class VIII4. Before the lesson was started, the students and teacher prayed together and they listened to reflection morning that brought by one of the teachers at the school. Then, greeted the students by saying "Good morning students, how are today?" and they answered "Good morning Miss, I am fine, and you?". Then I replied " I am fine, thank you". After greeted the students, I checked the attendance list. In class VIII-4 consisted of 29 students, 12 males and 17 females. At the time, students class VIII-4 was present.

I started the teaching learning process by reviewing and recalled the lesson last meeting. For example, I asked about the narrative text entitled Bawang Merah and Bwang Putih. For this meeting, I gave the test to evaluate their reading comprehension. The test formed multiple choices and the text in the test about Bawang Merah and Bawang Putih. It was as formative test in Cycle II. They did the test individually for 15 minutes. After they had finished do the test, I divided them to be pair and I gave the title of narrative text to students about Timun Emas to discuss with their pair or peer.

Then I gave to them the general question to think individually that what they known about Timun Emas for 5 minutes. After that, I asked them to share and to make report from what they thinking about Timun Emas in their partner or peer. When the time was over, I collected the students' work.

Before closing the lesson, I asked about students' difficulties in this meeting. Then, I gave the explanation and supported them to learn more. Then I said "This the end our meeting for today and see you next time" and they answered "see you Miss". Then, I left the class.

\section{h. Meeting 8 : Posttest}

The Posttest was held on Wednesday, 02 November 2016 at 08.50-10.10 hours in class VIII-4. I came in to the class and greeted the students by saying "Good morning students, how are today?" and they answered "Good morning Miss, I am fine, and you?". Then I replied "I am fine, thank you". After greeting, I checked their attendance list. In class VIII-4 consisted of 29 students, 12 males and 17 females. At the time, students class VIII-4 was present.

In this meeting, I suggested the students to do the test without cheating and I distributed the posttest to the students and explained what the students would do in the posttest. I provided 40 minutes to do the multiple choices test which consisted of 20 items about narrative texts and I distributed test 29 sheets. Then, I said "Enough for today students and see you next time". They answered "See you Miss". Then, I left the class.

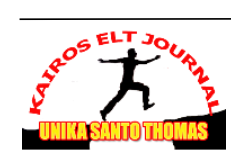


KAIROS ELT JOURNAL, Vol. 2, No. 1, April 2018

Copyright $\odot 2018$, ISSN: 2580-4278

Based on the field notes, I could be known the situation, activity and participant of students class VIII-4 in learning process. From the result of field notes, Think Pair Share technique can improve students reading comprehension. After applying Think Pair Share technique, Students was more active and more conducive in learning process.

\section{The Quantitative Data}

Quantitative data was taken from the result of the Pretest, Cycle I, Cycle II, and Posttest. The Pretest was administered before treatment and the Posttest was administered after the treatment. It was described as follows:

\section{Pretest}

After collecting the Pretest, I calculated the students' score of Pretest. The result of pretest could be seen Appendix 1.

\section{Table 1. Pretest Rank}

\begin{tabular}{|l|l|l|}
\hline No & Explanation & Students' Score \\
\hline 1 & The highest score & 80 \\
\hline 2 & The average score & 61,20 \\
\hline 3 & The lowest score & 35 \\
\hline
\end{tabular}

Based on the table 1., it showed that the average score of pretest was 61,20 . There was one student got 80 as the highest score and one student got 35 as the lowest score. After calculating the pretest score, I calculated the categories of students' reading comprehension. It could be seen in the following table:

Table 2. The Data Frequency of Students' Score Pretest

\begin{tabular}{|l|l|l|l|l|}
\hline No & Score Interval & Category & Students & Percentage \\
\hline 1 & $90-100$ & Very good & 0 & $0 \%$ \\
\hline 2 & $70-89$ & Good & 8 & $27,58 \%$ \\
\hline 3 & $50-69$ & Fair & 19 & $65,51 \%$ \\
\hline 4 & $30-49$ & Poor & 2 & $6,89 \%$ \\
\hline 5 & $0-29$ & Very poor & 0 & $0 \%$ \\
\hline
\end{tabular}

The table 2, showed that 8 students were in good category (27\%), 19 students were in fair category $(27,5 \%)$, and 2 students were in poor category $(6,8 \%)$.

\section{Cycle I}

After teaching reading comprehension using Think Pair Share technique, I distributed the test to the students. Then, I collected the result of the test, and calculated the score. The result of the test could be seen in the Appendix 1.

Table 3. Cycle 1 Rank

\begin{tabular}{|l|l|l|}
\hline No & Explanation & Students' Score \\
\hline 1 & The highest score & 100 \\
\hline 2 & The average score & 63,44 \\
\hline 3 & The lowest score & 40 \\
\hline
\end{tabular}

Based on the table 4.3 , it showed that the average score of pretest was 63,44 . There were three students got 100 as the highest score and seven students got 40 as the lowest score. 
KAIROS ELT JOURNAL, Vol. 2, No. 1, April 2018

Copyright $\odot 2018$, ISSN: 2580-4278

After calculating the post test score, I calculated the categories of students' reading comprehension. It could be seen in the following table:

Table 4. The Data Frequency of Students' Score Cycle 1

\begin{tabular}{|l|l|l|l|l|}
\hline No & Students' Score & Explanation & Students & Percentage (\%) \\
\hline 1 & $90-100$ & Very good & 3 & $10,34 \%$ \\
\hline 2 & $70-89$ & Good & 6 & $20,68 \%$ \\
\hline 3 & $50-69$ & Fair & 13 & $44,82 \%$ \\
\hline 4 & $30-49$ & Poor & 7 & $24,13 \%$ \\
\hline 5 & $0-29$ & Very poor & 0 & $0 \%$ \\
\hline
\end{tabular}

The table 4 . The table showed that 3 students were in very good category (10,3\%), 6 students were in good category $(20,6 \%), 13$ students were in fair category $(44,8 \%)$, and 7 students were in poor category $(24,1 \%)$.

\section{Cycle II}

After teaching reading comprehension using Think Pair Share technique, I distributed the formative test to the students in Cycle II. Then, I collected the result of the test, and calculated the score. The result of the test could be seen in the Appendix 1.

Table 5. Cycle II Rank

\begin{tabular}{|l|l|l|}
\hline No & Explanation & Students' Score \\
\hline 1 & The highest score & 100 \\
\hline 2 & The average score & 71,72 \\
\hline 3 & The lowest score & 40 \\
\hline
\end{tabular}

Based on the table 5., it showed that the average score of pretest was 71,72. There were two students got 100 as the highest score and one student got 40 as the lowest score. After calculating the post test score, the writer calculated the categories of students' reading comprehension. It could be seen in the following table:

Table 6. The Data Frequency of Students' Score Cycle II

\begin{tabular}{|l|l|l|l|l|}
\hline No & Students' Score & Explanation & Students & Percentage (\%) \\
\hline 1 & $90-100$ & Very good & 2 & $6,89 \%$ \\
\hline 2 & $70-89$ & Good & 15 & $51,72 \%$ \\
\hline 3 & $50-69$ & Fair & 10 & $34,48 \%$ \\
\hline 4 & $30-49$ & Poor & 2 & $6,89 \%$ \\
\hline 5 & $0-29$ & Very poor & 0 & $0 \%$ \\
\hline
\end{tabular}

The table 6 The table showed that 2 students were in very good category $(6,8 \%), 15$ students were in good category $(51,7 \%), 10$ students were in fair category $(34,4 \%)$, and 2 students were in poor category $(6,8 \%)$.

\section{Posttest}

After conducting the Cycle I and Cycle II, I did the posttest. The result of data could be seen in the Appendix 1.

Table 7. Posttest Rank

\begin{tabular}{|l|l|l|}
\hline No & Explanation & Students' Score \\
\hline
\end{tabular}


KAIROS ELT JOURNAL, Vol. 2, No. 1, April 2018

Copyright $\odot 2018$, ISSN: 2580-4278

\begin{tabular}{|l|l|l|}
\hline 1 & The highest score & 90 \\
\hline 2 & The average score & 75,51 \\
\hline 3 & The lowest score & 65 \\
\hline
\end{tabular}

Based on the table 7, it showed that the average score of pretest was 75,51. There were four students got 90 as the highest score and four students got 65 as the lowest score. After calculating the post test score, I calculated the categories of students' reading comprehension. It could be seen in the following table:

Table 8. The Data Frequency of Students' Score Posttest

\begin{tabular}{|l|l|l|l|l|}
\hline No & Students' Score & Explanation & Students & Percentage (\%) \\
\hline 1 & $90-100$ & Very good & 5 & $17,24 \%$ \\
\hline 2 & $70-89$ & Good & 19 & $65,51 \%$ \\
\hline 3 & $50-69$ & Fair & 5 & $17,24 \%$ \\
\hline 4 & $30-49$ & Poor & 0 & $0 \%$ \\
\hline 5 & $0-29$ & Very poor & 0 & $0 \%$ \\
\hline
\end{tabular}

The table 8 The table showed that 5 students were in very good category (17,2\%), 19 students were in good category $(65,5 \%)$, and 5 students were in fair category $(17,2 \%)$.

The percentage of each test administered to the students in this research after conducting the research at SMP Santo Petrus Medan, they were described as follows:

Table 9. The Data Percentages of Each Test

\begin{tabular}{|c|c|c|c|c|c|c|}
\hline No & Score & Explanation & Pretest & Cycle I & Cycle II & Posttest \\
\hline 1 & $90-100$ & Very good & $0 \%$ & $10,34 \%$ & $6,89 \%$ & $17,24 \%$ \\
\hline 2 & $70-89$ & Good & $27,58 \%$ & $20,68 \%$ & $51,72 \%$ & $65,51 \%$ \\
\hline 3 & $50-69$ & Fair & $65,51 \%$ & $44,82 \%$ & $34,48 \%$ & $17,24 \%$ \\
\hline 4 & $30-49$ & Poor & $6,89 \%$ & $24,13 \%$ & $6,89 \%$ & $0 \%$ \\
\hline 5 & $0-29$ & Very poor & $0 \%$ & $0 \%$ & $0 \%$ & $0 \%$ \\
\hline
\end{tabular}

The table 9 showed that there was a significant percentage in the students' reading comprehension. Based on the percentage score, the students got score $\geq 70$ in the pretest was $27,5 \%$ students, in Cycle I was 30,6\% students, in Cycle II was 58,5\%, and in the Posttest became 82,7 5 who fulfilled the KKM. It showed that there was an improvement of students' reading comprehension after applying Think Pair Share technique at the eighth grade students of class VIII-4 of SMP Santo Petus Medan.

The mean score each test administered to the students could be seen in the table follows:

Table 10. The Mean and Percentage Score of Each Test

\begin{tabular}{|l|l|l|}
\hline Test & Mean Score & Percentage $\geq 70$ \\
\hline Pretest & 61,20 & $27,5 \%$ \\
\hline Cycle I & 63,44 & $30,6 \%$ \\
\hline Cycle II & 71,72 & $58,5 \%$ \\
\hline Posttest & 75,57 & $82,7 \%$ \\
\hline
\end{tabular}

The table 10 showed that there was a significant improvement in the students' reading comprehension. In the Pretest the mean score was 61,20, but in the Posttest became 75,57. It showed that there was an improvement of the students' reading comprehension after applying 
Think Pair Share technique at the eighth grade students class VIII-4 of SMP Santo Petrus Medan.

\section{Discussion}

The data analysis of the present class action study shows the effectiveness of Think Pair Share technique in improving the students' reading comprehension. The mean pretest scores that obtained by students class VIII-4 in reading skill shows the mean figure of 61,20 . This mean figure clearly showed that the pre-existing reading comprehension of the subjects under study was relatively low.

The result of the data analysis of formative test score in cycle I shows the increasing mean figures of 63,44 . The mean of formative test in cycle I was much higher than the result of the pretest. The mean figure for formative test of cycle I showed that the reading comprehension got an improvement after the student class VIII-4 had been taught through Think Pair Share technique.

The result of the data analysis of the formative test scores in cycle II that obtained by students class VIII-4 shows that the increasing mean figures of 71,72. The mean figure obtained by students class VIII-4 in cycle II is convincingly much higher than the mean figure of pretest scores. There is a significant difference of the mean figure between formative cycle I and cycle II are 8,22 (71,72-63,44). The significant difference of the mean figure suggested that the teaching reading in cycle II through Think Pair Share technique could be remarked to be more effective than cycle I.

Based on result of analyzing data, it could be seen that the mean score the pretest and the mean score posttest are difference of the results of data. So, it can be concluded that students' reading comprehension improve after applying Think Pair Share technique at the eighth grade students class VIII-4 of SMP Santo Petrus Medan.

\section{CONCLUSIONS}

The purpose of this study is to improve the students' reading comprehension especially in narrative text. After I implemented of Think Pair Share technique at the eighth grade students class VIII-4 of SMP Santo Petrus Medan in the academic year 2016/2017. I make conclusion that students have improvement in reading comprehension. It can be seen from the results of students' mean score of the pretest, post-test in cycle I and post-test in cycle II. The mean score of the initial reflection or pre-test was 61,20 . On the other hand, after the treatment was given, the mean figure of the post-test score in cycle I was 63,44. In addition, The mean figure of the post-test scores in cycle II was 75,51 and it was included as enough level of qualification. It also can be seen from the percentage of students score who fulfilled the KKM $\geq 70$, which was $27,5 \%$ in the Pretest and became $82,7 \%$ in the Posttest. It can be concluded that there is a significant mean score improvement between Pretest and Posttest about 55,2\%. It proves that Think Pair Share technique can improve students' reading comprehension.

Therefore, in this research proves and shows that the problems on reading faced by the eighth grade students of SMP Santo Petrus Medan in academic year 2013/2014 could be overcome through Think Pair Share technique in reading comprehension. The technique is useful to change the students' behavior in English teaching and learning process because the student could explore their skill in comprehending the material reading through discussion with their peers or partners. It could be concluded that Think Pair Share technique is an effective technique used to improve the students' ability in reading comprehension. 


\section{BIBLIOGRAPHY}

Andreson, Neil. "What is Reading?". In Nunan, D. ( $3^{\text {rd }}$ Ed). Practical English Language Teaching. New York: Mc Graw Hill. 2003.

Azlina, N. CETLs : Supporting Collaborative Activities Among Students and Teachers Through the Use of Think-Pair-Share Techniques. "Journal of Computer Science Issues". 2010. 7(5),23.

Best. W. Jhon and Khan. V. James. Research in Education ( $7^{\text {th }}$ Ed). New Delhi: Prentice-Hall. 2002.

Brown, H. D. Teaching by Principles an Interactive Approach to Language Pedagogy 2nd. Englewood Cliffs: Prentice Hall Regents. 2001.

. Language Assessment Principles and Classroom Practices. New York: Pearson Education. 2003.

Burns, C.P, Roe. D.P and Ross, B.E. Teaching Reading in Today's Elementary Schools. Boston: Houghton Mifflin Company. 1984.

Copper, James. M. Classroom Teaching Skills. Boston: Houghton. 1988.

Grabe, W., \& Fredrika L.S. Teaching and Researching Reading. New York: Pearson Education. 2002.

Heilman, A. W., Blair, T., Rupley, W. Principles and Practices of Teaching Reading. Ohio: Charles E. Merril Publishing Company. 1981.

Jolliffe, W. Cooperative Learning in the Classroom. London: The Cromwell Press. 2007.

Kingner, J., Vaughn, S., and Boardman, A. Teaching Reading Comprehension on the Students with Learning Difficulties. London: The Guilford. 2007.

Latief, M. A. Research Method an Language Learning : An Introduction. Malang: UM Press. 2012.

Limbong, T., Simanullang, P., \& Napitupulu, E. (2016). Aplikasi Pembelajaran Pengenalan Angka Untuk Usia Dini Menggunakan Objek Gambar Benda (Studi Kasus SD Negeri No. 173395 Dolok Sanggul). Seminar Nasional Ilmu Komputer (SNIKOM), October, 73-81. https://doi.org/10.13140/RG.2.2.29625.57442

Listiani, K. N. Improving Reading Comprehension Through Think Pair Share at the Eighth Grade Students of SMPN 2 Abiansemal. A Thesis, Unpublished. Mahasarwati Denpasar University. 2014.

Mettetal, G. The What, Why and How of Classroom Action Research. "The Journal of Scholarship of Teaching and Learning (JoSoTL)”. 2001 2(1), 8.

Moreillon, J. Collaborative Strategies for Teaching Reading Comprehension. Chicago: Houghton Mifflin Company. 2007. 
KAIROS ELT JOURNAL, Vol. 2, No. 1, April 2018

Copyright@2018, ISSN: 2580-4278

Snow, C.E. Reading for Understanding Toward an R \& D Program in Reading Comprehension. Arlington: RAND Education. 2002.

Sriwahyuni, E., \& Ohoiwutun, E. Developing reading comprehension of the eleventh grade students through think pair share technique. "Journal of English language teaching society (ELTS)”. 2014. 2(2), 2-3.

Syahputra, Adly and Ginting M. Elia. Improving Students' Achievement In Writing Narrative Text Through Think Pair Share Technique. A Thesis, Unpublished. Unimed. 2006.

Tampubolon, M. Penelitian Tindakan Kelas Sebagai Pengembangan Profesi Pendidik dan Keilmuan. Jakarta: Penerbit Erlangga. 2014.

Tint, S., \& Nyunt. E. Learning Strategy with Groups on Page Based Students' Profiles. “ $A n$ international journal (ACII)". 2015. 2 (1), 2.

Utama, IM. Permadi. The Effect of Think Pair Share Technique Strategy to students' SelfConfidence and Speaking Competency of the Second Grade Students of SMPN 6 Singaraja. A Thesis, Unpublished. E-journal Pscasarjan Undiksha. 2013.

Westwood, P. Reading and Writing Difficulties. Camberwell: ACER Press. 2007.

Winter, R., \& Giddings, C. A Handbook for Action Research in Health and Social Care. New York: Routledge. 2001. 